\title{
THE EFFECTS OF CREDIT FINANCING IN AGRICULTURE ON THE DOMESTIC PRODUCT IN AGRICULTURE IN THE REPUBLIC OF SERBIA
}

\author{
Ranisavljević Duško ${ }^{1}$
}

\begin{abstract}
In recent years, the banking sector has increasingly turned to the agricultural sector. There is a noticeable increase in the total claims of the banking sector from registered farms in the period 2012-2020, while the part of the domestic product generated by the agricultural sector also recorded growth, but not in the same percentage as bank loans to agriculture. The aim of this paper is to examine the interdependence of the increase in total claims of banks on registered agricultural producers with the increase in the domestic product generated by the agricultural sector. The method of statistical correlation was used in this paper. The impact and changes of investment loans in agriculture, loans for working capital, but also the change in bank claims from agricultural producers based on interest and fees have been analyzed. The conclusion is that there is a connection between loans and the domestic product of the agricultural sector, but that there are other factors that have an impact, too. Although in recent years the banking sector has been more open to the agricultural sector and although loans have become more affordable, it is necessary to create conditions for even greater availability of loans to agricultural producers, which would create positive effects on agriculture.
\end{abstract}

Keywords: agricultural loans / investment loans in agriculture / domestic product.

1 Singidunum University Faculty of Health and Business Studies 14000 Valjevo, Železnička 5, e-mail:dranisavljevic@singidunum.ac.rs 


\section{INTRODUCTION}

Agricultural financing and financing models are topics of great importance for the agricultural sector. Financing of the agricultural sector is done in two directions. The first is financing by the state, through various subsidies, grants, and various benefits, and the second is through borrowed funds, loans, both by various development funds and by commercial banks. Grants are not enough to accelerate the development of the agricultural sector, as well as the contribution of the agricultural sector to the total domestic product of national economy, so the question arises whether and to what extent borrowed funds compensate for this shortcoming.

The importance of borrowed funds and the contribution they make to the development of not only the agricultural sector but also other sectors of the economy, are topics of great importance.

The agricultural sector has undergone significant transformations in the last few decades. The challenges in which the entire domestic economy found itself affected the agricultural sector as well. Before any analysis, it is necessary to consider the situation in the agricultural sector in recent years, its specifics and opportunities for further development. According to the data of the Statistical Office of the Republic of Serbia, published in 2019, in the period from 2012-2018, the number of agricultural farms decreased by $9.9 \%$, with a slight increase in used arable land of $1.1 \%$ in the same period, with a noticeable increase in farms with the larger utilized area. There is also a noticeable decrease in the number of farms that cultivate land up to 2 ha, and the average area of agricultural land in this period was 6.1 ha. In the same period, 8 out of 10 farms were engaged in cattle fattening, while the average age of the owner of a farm was 61 , which is two years more than in 2012. In addition to the decline in livestock production, some positive trends are also noticeable, such as the modernization of mechanization, through a $10 \%$ increase in the number of tractors. In the same period, there was a noticeable increase in perennial crops by $10.2 \%$ (SORS, 2019).

On the other hand, the banking sector in the Republic of Serbia has also undergone significant transformations in the last two decades. There are many foreign banking groups, which, by taking over domestic banks and obtaining a direct operating license from the NBS, have increased 
competitiveness in the domestic banking market, and all banks have entered one market competition, opting for certain market segments, considering risks and benefits that each segment carries.

Banks, therefore, adjusted their business policies depending on risk assessment, current central bank regulations, and founders' decisions. Some banks estimated that the most important business segment was the retail segment, others focused on working with small and medium enterprises and entrepreneurs, some targeted large corporate clients and investment banking, while some successfully covered several different business segments.

In addition to the mentioned sectors, several banks also focused on the agricultural sector, but in different ways. Some of them actively promoted their products and services to registered agricultural producers, and some of them adjusted to the activities of financing agricultural activities. These banks did not promote the so-called "declarative" offers of loans to agriculture, but products and services that are designed and presented with the desire to increase outstanding credit in the agricultural sector. These are different credit products, with different maturities, different security instruments, denominated in dinar or foreign currency, which gives interested farmers more opportunities to find the necessary and adequate loan arrangement for their business. Until the period of affirmation of agricultural loans, some banks shyly promoted loans that they called agricultural, with quite rigid conditions in terms of interest rates and collateral. Their outstanding agricultural loans was quite small.

Banks that have decided to focus their financial potential more on the agricultural sector, have organizationally adjusted to this activity. At the level of bank headquarters, entire sectors and departments have been formed that specialize in this type of banking business. At the level of the business network of banks, separate regional units were formed within the branches (sub-branches and local offices), which covered a certain geographical area, a certain region. At the level of human resources, commercial banks have profiled various job positions (agribusiness manager, agricultural loan officer, agricultural loan risk analyst, etc.), which are closely specialized in working with farms, cooperatives, and other legal entities operating in the agricultural sector. 
Credit products were successively adjusted to the needs of the agricultural sector. Short-term and medium-term loans covered the needs of farmers for working capital, while long-term loans covered the needs for investments in equipment, agricultural machinery, long-term plantations, various agricultural facilities, and capital investments in general.

All the above contributed to an increase in the outstanding of these banks in the field of agricultural loans, and in a significant percentage, which gave the basic motive to assess the effects of these increased credit placements of banks to the agricultural sector. The main goal of this paper is to examine the impact of borrowed funds on the economic results of domestic agriculture, embodied in the gross domestic product, which is generated by the agricultural sector, to examine the interdependence and intensity of that interdependence.

The main hypothesis in the paper is the claim that loans of the banking sector have a significant impact on the share of the agricultural sector in the domestic product, but that other factors affect growth. An increase in banking sector loans does not necessarily imply an increase in agricultural production. A separate hypothesis is a claim that investment loans have a specific impact on output growth in the agricultural sector, as well as the claim that lower interest rates increase banks' lending activity to registered agricultural producers, which is further correlated with the domestic product in the agricultural sector.

The credit aspect of the analysis can be viewed from the angle of illiquidity and the angle of availability of long-term sources of financing for agriculture. The various subsidies received from the state are certainly not sufficient, and by their nature, they are sources that are relatively small in amount and can meet partial needs for working capital, i.e., to settle current illiquidity. Short-term bank loans are intended to finance working capital and current illiquidity.

Long-term loans are intended to finance long-term plantations, investments in equipment, machinery, facilities, basic herds, etc. Investing in economic entities either from their own or from other people's sources is a precondition for growth and development (Hadžić, 2018). 
When profiling credit products, banks first consider credit risk, which determines interest rates. Bank credit risk is defined as the probability that borrowers will not repay loans at maturity with interest. (Ćirović, 2006). The most important risk to which the bank is exposed in business is credit risk (Todorović, 2009). The collateral instruments of each loan are a significant segment of credit policy design and, in a way, the cancellation of credit risk. Collateral instruments are an important factor, and often eliminating, when it comes to credit borrowing of agricultural farms. The availability of collateral instruments is of great importance for the realization of loans. The usual collateral instruments are a mortgage on real estate and land, pledge on equipment, guarantee, deposit, pledge on stocks of agricultural products, etc. When it comes to mortgage security, the biggest problem is the legal correctness of real estate (registration of buildings and unresolved ownership). A special problem is the assessment of the market value of the real estate because that limits both banks and agricultural farms. The existing equipment and machinery are quite old, so mainly new assets, which are the subject of new loans, are being pledged. The guarantee can be either the guarantee of natural persons or the guarantee of other legal entities or entrepreneurs. The availability of this type of collateral is also questionable. Usually, the spouse, or the heirs of the holder of the holding give a personal guarantee for the loans of the agricultural holding. Collateral instruments are often combined, to cancel the credit risk. Certainly, if the estimated credit risk was lower, and if the collateral requirements were somewhat lower, it is certain that the credit activity of banks would increase, and thus the effects on the agricultural sector.

Based on the Conclusion of the Government of the Republic of Serbia, and at the proposal of the Ministry of Agriculture, Forestry and Water Management, in December 2017, the National Program for Agriculture 2018-2020 was adopted. According to this document, the incentive for agricultural production is based on the following incentives: direct payments, incentives for rural development measures, special incentive measures, and credit support, all defined by the Law on Incentives in Agriculture and Rural Development, while specific amounts are defined by annual decrees of the Government of the Republic of Serbia. In 2017, this amounted to $87 \%$ for direct payments, $9.6 \%$ for rural development measures, $1.6 \%$ for special incentives, which in the end gives only $2 \%$ for 
incentives in credit support. From the same source in the previous period, due to the simplified banking procedure, credit funds were spent inappropriately, so in 2008 the interest rate was switched to subsidized, which contributed to the improvement of credit collateral procedures through the possibility of establishing collateral on future agricultural products. The competent ministry contracts with selected commercial banks that can implement this type of lending, all to improve the longterm offer of bank loans for the agricultural sector in Serbia. The goal set by the Government of the Republic of Serbia in 2017 is for the level of subsidized loans to reach 13.3 billion dinars in the next three-year period, for the number of users (entities) using these lines to reach 6,600 , and for the interest rate to be in the stimulating range. $1-2 \%$. Of course, at that time, the negative impact on society and the economy, caused by the Covid 19 pandemic, could not be predicted.

\section{THEORETICAL BACKGROUND}

On the topic of the interdependence of the agricultural sector and the availability of different sources of financing for agriculture, many papers have been written and a lot of research has been done. These works mainly dealt with the analysis of various sources of financing, from state subsidies, through loans from development funds to commercial sources of financing.

The specificity of this paper is reflected in the consideration of the interdependence of credit financing of the agricultural sector in the Republic of Serbia and the domestic product in the agricultural sector in the period 2012-2020. Such analysis and research have not been done, which gives importance to the research and results presented in this paper.

In theory, sources of agricultural financing are grouped similarly. The most common sources of financing agriculture are self-financing, loans, and incentives. In the last decade and a half, it is obvious that the banking sector has not been in favor of significant financing of agriculture, due to the risks manifested in the yields and prices on the market, and due to the unavailability of security instruments (Zakić and Kljajić, 2016). Domestic agricultural producers identify problems when applying for loans in the price of capital, complicated procedures, but also transparency in resolving their loan applications. (Njegomir et al., 2017). 
In theory and practice, there are, for our climate, quite specific sources of funding. One such source of financing is financing by Islamic financial institutions, because their loans do not use interest, and the interest expenses of domestic farmers are not small. Also, these financial institutions can establish business ties between domestic farmers and Islamic countries (Kačar et al., 2017).

To increase the credit activity of banks in the agricultural sector, better education of producers and lenders is needed, a better understanding of the needs of agricultural producers is needed, especially the risks of this production (Popović et al., 2018).

The issue of the financial capacity of agricultural companies is a significant topic in the European Union as well. According to a survey published in 2015 and conducted on 250 agricultural companies, in which different methods were used to predict the financial insolvency of agricultural companies, it was concluded that the accuracy of predicting financial bankruptcy decreases if the forecast period is longer (Klepac and Hampel, 2017). This indicates the specific characteristics of the financial aspect of the business of agricultural producers, which is certainly recognized by financial institutions, primarily commercial banks, so they incorporate the risks of financial bankruptcy into their procedures and business policies. In the European Union, a gap is identified between the target infrastructure for financing agriculture and the instruments available on the market, and the conditions for a comprehensive securitization mechanism for environmental loans backed by a public guarantee should be identified (Migliorelli and Dessertine, 2017). Considering that the EU Common Agrarian Policy envisages a reduction of the budget for agriculture by $15 \%$ for the period 2021-2027 year, the EU faces major challenges, to achieve economic sustainability of agricultural holdings and to align national goals with EU goals. (Đurić et al., 2020).

In the Netherlands, the average bank loan in 2015 was 740,000 euros per farm, but financing capacities are more limited to retain more capital to comply with the Basel Accords, and due to low returns on capital in agriculture, private financing is not present anymore (Meulen and Asseldonk, 2017).

Access to finance for financing agriculture is a topic of importance in other economies of the world. In India, lack of access to finance is a major 
cause of low profitability in agricultural production (Nisha, 2018). Better understanding and coordination of world institutions in the global advancement of agriculture are needed. Institutions such as the IMF need to adjust and improve their policies towards agricultural development, in cooperation with other important financial institutions such as the World Bank and the World Food Program. (Daoud et al., 2019). Lending to agriculture is quite diverse in the world. In recent years, farmers in Australia have been offered new, more complex forms of financing, which change the traditional bank debt, and it happens that financial capital has acquired ownership of land and water. (Larder et al., 2017).

Monetary policies have an impact on agricultural lending conditions. In the People's Republic of China (Targeted easing policy by the Chinese central bank), changes in monetary policy in the part of reducing the required reserve for agricultural lending, achieved positive effects, and encouraged lending to agriculture in the period 2012-2017, compared to other types of loans (Lin and He, 2020).

In literature, significant attention is paid to interest-free sources of agricultural financing, as well as non-refundable funds. For agricultural producers, the agrarian budget, non-refundable and interest-free funds of support for agricultural development are of special importance. Some authors have investigated whether the agrarian budget in the Republic of Serbia is aimed at the development of the agricultural sector, or - more precisely - the impact of the agrarian budget on the development of agriculture (Kuzman et al., 2017).

Lending to agriculture takes place through various types of bank loans, which in recent years have been more affordable and with more favorable interest rates. However, in the first decade of this century, interest rates in the domestic market and the risks faced by commercial banks determined higher interest rates. With the agrarian policies in the previous period, the state tried to make loans more accessible to agricultural producers with certain measures. Since 2004, these policies have been reflected in providing more favorable conditions for lending, through interest rate subsidies, for agricultural producers to obtain cheaper sources of financing. These are loans from commercial banks, subsidized by the Agrarian Budget to provide favorable conditions for lending, which contributes to the improvement of the overall rural 
economy (Bogdanov, 2007). For example, in Russia, mechanisms have been established to support the development of the agricultural sector by subsidizing the interest rates of Russian commercial banks, which has contributed to lowering the effective interest rate in Russia to $5 \%$ and below (Uzun, et al. 2019). In Serbia, continuous financing of agricultural production is necessary, but in the interest rate subsidy program, good coordination with the banking sector is important, so that banks are motivated to lend to the agricultural sector to a greater extent, because agriculture needs a larger amount of credit (Zelenović, et al. 2018).

\section{MATERIALS AND METHODS}

As a basis for the analysis, the data obtained from the Statistical Office of the Republic of Serbia and the National Bank of Serbia were used, which show the structure of claims of the banking sector from registered agricultural producers, and data on the domestic product in agriculture in the nine years: 2012-2020. In the table below (Table 1 below), there are data for each year individually:

Table 1. Claims of the banking sector and domestic product of agriculture in Serbia 2012-2020 (RSD 000.000)

\begin{tabular}{|c|c|c|c|c|c|}
\hline Year & $\begin{array}{c}\text { Investment } \\
\text { loans in } \\
\text { agriculture }\end{array}$ & $\begin{array}{c}\text { Liquidity } \\
\text { and } \\
\text { working } \\
\text { capital } \\
\text { loans }\end{array}$ & $\begin{array}{c}\text { Interest } \\
\text { and fee } \\
\text { claims }\end{array}$ & $\begin{array}{c}\text { Total claims of } \\
\text { the banking } \\
\text { sector on } \\
\text { registered } \\
\text { agricultural } \\
\text { producers }\end{array}$ & $\begin{array}{c}\text { Domestic } \\
\text { product - } \\
\text { agriculture } \\
\text { (current } \\
\text { prices) }\end{array}$ \\
\hline 2012 & 19,859 & 6,474 & 612 & 31,252 & $269,999.8$ \\
\hline 2013 & 22,468 & 6,917 & 597 & 33,994 & $305,519.7$ \\
\hline 2014 & 26,335 & 9,042 & 563 & 39,699 & $302,226.3$ \\
\hline 2015 & 29,494 & 9,445 & 554 & 43,632 & 273,858 \\
\hline 2016 & 34,770 & 12,016 & 567 & 51,606 & 308,422 \\
\hline 2017 & 39,142 & 14,100 & 360 & 57,498 & 286,315 \\
\hline 2018 & 43,902 & 16,118 & 338 & 63,914 & 321,765 \\
\hline 2019 & 48,928 & 16,900 & 320 & 69,565 & 322,560 \\
\hline 2020 & 52,009 & 25,094 & 340 & 80,422 & $354,920.6$ \\
\hline
\end{tabular}

Source: SORS number 269 and NBS 1.1.16/5 
The table summarizes the data for each year and shows the change in claims of the banking sector for the period from 2012-2020, as well as the turnover in the agricultural sector for the given period. The data for the domestic product in agriculture represent gross value added, without taxes, in current prices and are taken from the official website of the Statistical Office of the Republic of Serbia. In the last year, namely 2020, the annual data was obtained by summing the quarters, according to the Quarterly Report of the Statistical Office of the Republic of Serbia, which was the only one available at the time of writing.

The data are given in millions of dinars, and refer to the nine-year period, which characterizes the period of exit from the world economic crisis of 2008-2012, until 2020, when the Covid 19 pandemic appeared. In the first few years, after the economic crisis, negative effects were felt on the banking sector in terms of increased prudence of banks and the perception of greater credit risk, which of course did not bypass the agricultural sector.

It is noticeable that in 2012, the total claims of the banking sector from agricultural holdings amounted to 31,252 million dinars, and eight years later to 80,422 million dinars. This means that the receivables of the banking sector have increased by $157 \%$ in nine years, or in other words, the receivables of the banking sector have increased approximately two and a half times in the observed nine years, from registered agricultural producers. The agricultural sector increased its indebtedness by a significant percentage. For the same period in 2012-2020, the increase in GDP in agriculture was $31 \%$, but it should be borne in mind that in 2014 , 2015, and 2017 it there was a decrease compared to the previous year, while in all other years there was growth.

The trends in investment loans in agriculture and working capital loans, which represent the most important claims of banks, are presented in particular, according to the purpose (first two columns of Table 1). The third column shows claims for interest and fees for the specified period. Other claims, which are of a smaller amount, were not taken into consideration. The importance of investment loans is reflected in encouraging the development of the agricultural sector, capital, longterm investments, in the overall increase in the capacity of agricultural production, as a generator of domestic product in agriculture. 
On the other hand, like all businessmen, entrepreneurs and agricultural producers are economic entities that have gaps in illiquidity or a greater need for working capital. For this reason, working capital loans are analyzed. Also, the costs of lending to the economy are important, so these data are included in the analysis. The following chart (Figure 1) shows the change in total claims of the banking sector and domestic product in the agricultural sector for the eight years 2012-2020:

Figure 1. Change in loans according to purpose and domestic product in agriculture 2012-2020

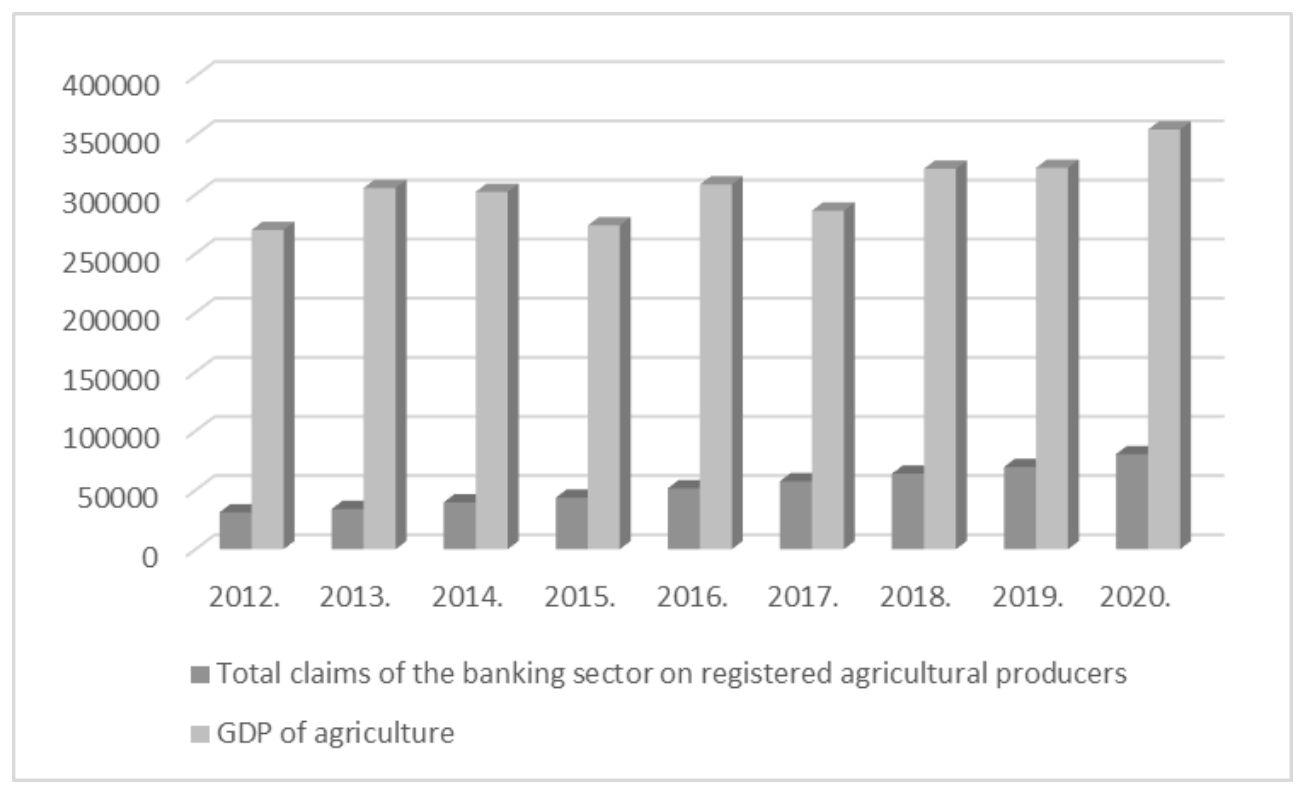

Source: SORS and NBS, 2012-2020

The following chart (Figure 2) clearly shows the trend of total claims of the banking sector, but also the trends of investment loans, working capital loans, and claims for interest and fees in the nine years: 
Figure 2. Bank claims: total loans, investment, working capital, and interest 2012-2020

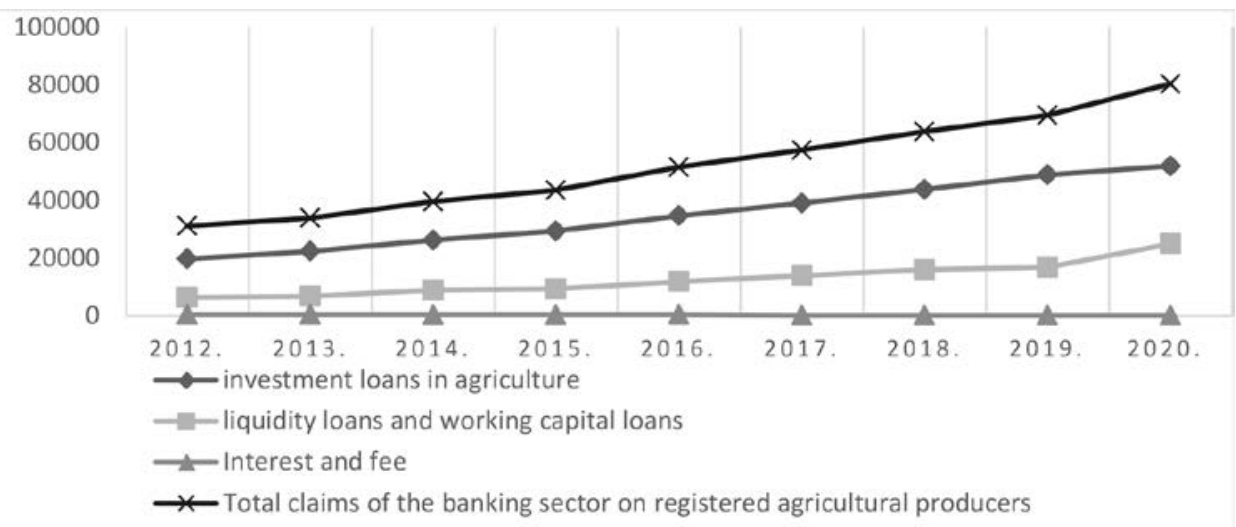

Source: SORS and NBS, 2012-2020

In addition to the comparative method, induction method, descriptive statistics, the method of statistical correlation has also been used in the paper. To determine the overall impact of banks' lending activity on the change of the domestic product in the agricultural sector, a statistical correlation will be used. As a measure of the connection between the two characteristics (claims of the banking sector and the domestic product in the agricultural sector by years), the Pearson correlation coefficient will be used, where the characteristic $\mathrm{x}$ is the demand of the banking sector and the characteristic $y$ is the domestic product in the agricultural sector, which gives the correlation coefficient $r=0.79293$, and the result of the coefficient of determination is $r^{2}=0.792932=0.62873=62.87 \%$.

Using the same statistical methodology, we determine the interdependence of banks' claims based on investment loans, separately, and the domestic product in the agricultural sector for the same period, 2012-2018. The correlation coefficient for these two features is: $r=$ 0.76601 , which gives the coefficient of determination $\mathrm{r}^{2}=0.58677=$ $58.67 \%$. 
Table 2. Summary of the results of correlation and interdependence

\begin{tabular}{|c|c|c|}
\hline Period 2012-2020 & $\begin{array}{c}\text { Correlation } \\
\text { coefficient- r }\end{array}$ & $\begin{array}{c}\text { Coefficient of } \\
\text { determination - } \mathbf{r}^{\mathbf{2}}\end{array}$ \\
\hline $\begin{array}{c}\text { Total claims of the banking } \\
\text { sector and domestic product } \\
\text { in agriculture }\end{array}$ & 0.79293 & $62.87 \%$ \\
\hline $\begin{array}{c}\text { Investment loans of } \\
\text { registered agricultural } \\
\text { producers and domestic } \\
\text { products in agriculture }\end{array}$ & 0.76601 & $58.67 \%$ \\
\hline
\end{tabular}

Source: Authors calculation

\section{RESULTS AND DISCUSSIONS}

Bearing in mind that the correlation coefficient is 0.793 , we conclude that there is a good, solid correlation between these two statistical characteristics, the claims of the banking sector and the domestic product in the agricultural sector in the given period, and considering the determination coefficient of $62.87 \%$ we can conclude that there is a solid interdependence between these two statistical features, that changes in banks' claims and lending activity affect changes in the domestic product in the agricultural sector. The banking sector encourages the development of agriculture, but there are certainly other, important factors, otherwise the obtained values would be higher.

If we look at the relationship and interdependence of investment loans with sales in the agricultural sector separately, given the correlation coefficient of $0.766 \%$, it can be concluded that there is also a solid correlation between these two statistical characteristics, in the analyzed nine-year period. A slightly lower coefficient of determination of $58.67 \%$ indicates that there is a solid interdependence between this type of loan and the domestic product in agriculture, but that it is not as prominent as in the ratio of total claims of the banking sector (all loans) and the domestic product in the agricultural sector. The specific characteristics of agricultural production, which is characterized by slow turnover, market uncertainty, contribute to the fact that investment ventures in agricultural production do not give visible effects in the medium term. It is possible that this indicator would have a slightly higher value if the period of observation and analysis was longer. 
In addition to the correlation analysis, by using the comparative and descriptive statistical method in the presented data, we see that there was an increase in total claims of the banking sector from registered farms by $157 \%$, from 2012 to 2020 and that the growth of GDP of the agricultural sector in the same period was $31 \%$. In the nine observed years, we have a constant growth of claims of the banking sector, but we also have three years in which, in addition to the growth of loans in the banking sector, the agricultural sector showed a decrease in the domestic product of agriculture (2014, 2015 and 2017). This means that although the banking sector showed greater confidence in the agricultural sector, in the observed period there were years when the effects of lending to the agricultural sector did not give the expected results. If we single out $2014 / 2015$, we will see an increase in the total claims of the banking sector from registered agricultural holdings of $10 \%$. If we look at the domestic product of the agricultural sector, we will see that in 2015, a decline of $9.4 \%$ was recorded compared to the previous year. In the same way, in 2017, the growth of credit claims of $17.5 \%$ compared to the previous year was accompanied by a decline in the domestic product of the agricultural sector of $7.1 \%$, which leads to the conclusion that in these years the influence of other factors was more pronounced.

However, in all other years of the analyzed period, the growth of claims of the banking sector is accompanied by the growth of the domestic product of the agricultural sector. The growth of claims by two and a half times, due to the previously described years of declines in sales, slowed down the overall growth of the domestic product in the agricultural sector, and did not give the expected effects - a higher growth rate. As the economic effects of investments in agriculture are calculated in the long run, due to the slow turnover and the nature of activities, we take into consideration a longer period, i.e., the entire period from 2012 until today, that is until 2020, by when the data is available for analysis. We conclude that there is an impact of the banking sector on the growth of the domestic product in the agricultural sector, but that it is not the only one. The influence of other factors may be the subject of a separate analysis.

If we look separately at the share of investment loans in the total claims of the banking sector on agricultural producers, we come to a relatively stable trend of participation of this group of loans in total loans. The 
share of investment loans ranges from $63.5 \%$, to a maximum of $70.3 \%$ of total claims of the banking sector on registered agricultural producers, so we can conclude that these loans in the period 2012-2020 account for about $2 / 3$ of total credit claims of banks from registered agricultural producers.

Considering the volume of loans, it can be concluded that in the mentioned period, significant investments were made in fixed assets, long-term plantations, and other capital investments of economic entities in the agricultural sector. The amount of these funds has multiplied in just a few years. In 2019, the share of these loans is the largest in the observed period, 2.49 times higher than in 2012. In the year before the Covid 19 pandemic, there was an increase in investment activity in agriculture, and this trend continued in early 2020, but although in absolute terms investment loans are the largest in the observed period, their share in total claims of the banking sector is smaller than in the previous year and amounts to $64.7 \%$.

On the other hand, if we look at liquidity loans and working capital loans, it must be emphasized that these funds are intended for settling current liabilities, most often the seasonal gap of illiquidity that is characteristic of the agricultural sector. The share of liquidity and working capital loans in total loans to the agricultural sector is quite interesting and varies from $20.3 \%$ to $31.7 \%$. The largest share of illiquidity loans is in 2020 , the year in which the negative economic effects of the pandemic caused general illiquidity of the economy, and thus an increase in the need of economic entities for additional working capital. This effect influenced agricultural producers as well. The agricultural sector normally requires significant working capital, especially in times of crisis. The growth of this type of loan both in absolute terms and in the share in total bank loans can be explained by the fact that working capital loans do not necessarily require "firm" credit security, so these loans are more accessible to most agricultural producers. They are usually approved with promissory note security, except when it comes to loans for permanent working capital. Then, due to the maturity and the amount, the banks insist on mortgage security. Long-term investment loans in agriculture and long-term loans for permanent working capital are often combined, as an optimal combination of borrowed funds, which enables agricultural producers to operate stably. The data that is the subject of 
the analysis indicate the growth of both groups of loans. Loans for permanent working capital encourage the solvency of agricultural producers, i.e., the ability to settle liabilities in a longer period, and a larger share of this type of loan is to be expected in the future.

Of particular interest is the share of interest and fee claims in total claims of banks in the agricultural sector. In the given data for the period 20122020 , there was a decrease in the share of claims from $1.95 \%$ in 2012 to $0.42 \%$ in the last observed year, 2020. Interestingly, the exposure of banks increased two and a half times in the same period, and the share in claims for interest and fees fell 4.6 times. The explanation for this trend lies in the fact that in the observed period, interest rates on loans became significantly cheaper. It is to be expected that due to the growth of outstanding (total bank claims), total interest claims will also grow, but this did not happen. There has been a significant change in interest rates in the interest rate market. Both domestic and foreign reference interest rates became cheaper, which made interest rates on loans cheaper. For example, the most used reference interest rate on loans indexed in EUR (long-term loans) 6M Euribor decreased from 1.606\% in January 2012 to a rate of $(-) 0.508 \%$, which is a decrease of $2.114 \%$ for the period 2012 2020 which is being analyzed (Euribor-rates, 2021). The conclusion is that the fall in reference interest rates caused lower interest rates on loans which caused an increase in lending activity, which further had certain effects on the agricultural sector.

The increase in competitiveness between banks in the segment of agricultural lending has contributed to the adjustment of interest rates and bank fees all to attract as many loan users as possible - agricultural producers. And in the tariffs of fees, there was an obvious reduction in prices. The fees paid by loan users are loan processing fees, various loan administration and monitoring fees, early repayment fees, and other fees, and they decreased in the observed period. The fact is that the agricultural sector has received adequate and good support in the banking sector, that both short-term and long-term loans are more accessible and affordable, but that there is certainly a lot of room for further improvement. 


\section{CONCLUSIONS}

The paper confirms the main hypothesis, which is the claim that the increase in credit claims of the banking sector to registered agricultural producers is in connection with the growth of the domestic product generated by the agricultural sector, observed in the period 2012-2020. The lending activity of banks has increased significantly in this period, and as determined and described in the previous part of the paper, it has an impact on the domestic product in agriculture, but this impact is not the only one. The annual turnover of the agricultural sector is also influenced by weather conditions, the market price of agricultural products, subsidy policy, and much more, and not only the credit policy of commercial banks. Therefore, the impact of lending to the banking sector on the agricultural sector over a multi-year period is analyzed.

The analysis found that investment loans are important for the agricultural sector, which confirmed a separate hypothesis, but we should not ignore the impact of working capital loans, whose growth during the observed period was most pronounced.

The increase in the volume of working capital and liquidity loans in 2020 is justified by the needs of the agricultural sector caused by the increase in the illiquidity of the entire domestic and global economy, caused by the Covid pandemic 19. The share of this type of loan in total bank claims is the largest this year, and the increase since 2012 is also very noticeable.

The reduction of reference interest rates conditioned the reduction of interest rates on loans, which affected lending to the agricultural sector. From year to year, due to the measures of central banks, reference interest rates decreased, so interest rates fell. Loans have become cheaper, and credit exposure has increased, and his has certainly contributed to an increase in output in the agricultural sector, observed in the period 2012-2020. Banks' credit exposure to registered producers increased by two and a half times and interest and fee claims almost halved. This supports the claim that for the banking sector, the agricultural sector is less risky than in previous years, and that if this trend continues, the lending activity of banks in the agricultural sector will increase further, if the negative economic effects of the Covid 19 pandemic do not significantly thwart these trends. The analyzed 
indicators unequivocally indicate the conclusion that the banking sector has increasing confidence in the agricultural sector, which is an obvious consequence of the trend of slightly higher exposure of banks and somewhat lower credit risk in the entire economic system of the country. The increase in investment loans in agriculture is proof that capacities will increase in the medium and long term, and that the effects of investments will be more visible in the future.

The domestic product in agriculture is also affected by other loans, loans of natural persons-family members, funds provided from other sources, private loans, sale of inheritance, in addition to "classic" economic loans and subsidies, and other types of state support. When talking about the contribution of the agricultural sector to the country's domestic product, one should keep in mind all the specific characteristics of this sector, seasonal impact, weather conditions, and instability of the market and prices of most agricultural products, which leads to the conclusion that the domestic product in agriculture is determined by various factors besides support from commercial banks. All the above leads to the conclusion that the banking sector has and should have a lot of room for improving access to the agricultural sector, both in new and more favorable financial products and services, as well as through improving the process, which will increase the positive impact on the agricultural sector. The banking sector recognizes the risks and its exposure to the agricultural sector is an indicator of the economic perspective not only of this sector but also of the national economy as a whole.

\section{REFERENCES}

1. Bogdanov, N. (2007). Small rural households in Serbia and rural non-agricultural economy, Belgrade, Ministry of Agriculture-UNDP, 78-82.

2. Ćirović, M. (2006). Banking, European Center for Peace and Development, Belgrade p.347.

3. Conclusion of the Government of the Republic of Serbia on the National Program for Agriculture 2018-2020. year, Official Gazette of RS, number 120/17. 30.dec. 2017.

4. Daouda, A., Reinsberga, B., Kentikelenisb, A.,Stubbsa, T., Kinga. L., (2019). The International Monetary Fund's interventions in food and 
agriculture: An analysis of loans and conditions, Elsevier, Food Policy 83. 204-218.

5. Đurić, K., Tomaš Simin, M., Glavaš Trbić, D., Lukač Bulatović, M. (2020). Challenges of the common agricultural policy of the European Union in the period after 2020, Economics : theory and practice, Year XIII, Vol. III, FIMEK Novi Sad, p. 43.

6. Euribor rates (2021), Retireved from https://www.euriborrates.eu/en/euribor-rates-by-year/2020/ (March 15, 2021)

7. Hadžić, M. (2018). Banking, Singidunum University, Belgrade p. 191.

8. Kačar, B., Curić, J., Ikić, S. (2017). Islamic banks and finance and possibility of agricultural investments in the Republic of Serbia, Economics of Agriculture, Vol. 64, No. 3, 1081-1100.

9. Klepac V., Hampel D. (2017). Predicting financial distress of agriculture companies in EU. Agric. Econ. - Czech, 63, 347-355. doi: 10.17221/374/2015-AGRICECON .

10. Kuzman, B., Đurić K., Mitrović Lj., Prodanović, R. (2017). Agricultural budget and agriculture development in Republic of Serbia, Economics of Agriculture, Vol. 62, No. 2, 515-531.

11. Larder, N., Ruth Sippel, S., Argent, N. (2017). The redefined role of finance in Australian agriculture, Australian Geographer, doi: 10.1080/00049182.2017.1388555.

12. Law on Agriculture and Rural Development, Official Gazette of RS, no $41 / 09,10 / 13$ i $101 / 16$

13. Lin, C., He L. (2020). Targeted Monetary Policy and Agriculture Business Loans, North American Journal of Economics \& Finance, Elsevier, doi.org/10.1016/j.najef.2020.101290 1-35.

14. Meulen, H., Asseldonk, M. (2017). Mainstream and alternative sources of finance in Dutch agriculture, Paper for the 21th International Farm Management Congress, Edinburgh - sub theme: Financing farm business. 1-15.

15. Migliorelli, M., Dessertine, Ph. (2017). Time for new financing instruments? A market-oriented framework to finance environmentally friendly practices in EU agriculture. Journal of Sustainable Finance \& Investment, doi: 10.1080/ 20430795.2017.1376270 1-26 
16. Nisha, B., (2018). Evolution of agriculture finance in India: a historical perspective. Agricultural Finance Review, Vol. 78 Issue: 3. 376-392,

17. Njegomir, V.,Tepavac, R., Ivanišević N. (2017). Alternative sources of financing entrepreneurial undertakings in agriculture, Economics of Agriculture, Vol. 64, No. 1, 295-306.

18. National Accounts Statistics, Gross Domestic Product 2019 (Statistical Office of the Republic of Serbia, Report No.269) Retireved from www.stat.gov.rs (October 1, 2020)

19. National Accounts Statistics, Gross Domestic Product 2015. (Statistical Office of the Republic of Serbia, Report No. 260) Retireved from www.stat.gov.rs (September 30, 2016)

20. Popović, S., Janković, I., Stojanović, Ž. (2018). Značaj bankarskih kredita za finansiranje poljoprivrede u Srbiji. Economics of Agriculture, Vol. 65, No. 1, 65-80. doi:10.5937/ekoPolj1801065P

21. Quarterly gross domestic product in the Republic of Serbia (Statistical Office of the Republic of Serbia, Report No.54) (2021) Retireved from www.stat.gov.rs (March 1, 2021)

22. Survey on the structure of agricultural holdings 2012-2018. (SORS) Retireved from www.stat.gov.rs (April 19, 2019)

23. Structure of banks' claims on registered agricultural producers by purpose (NBS report), available at https://www.nbs.rs/sr_RS/ drugi-nivo-navigacije/statistika/detaljni_potrazivanja/ (February $25,2021)$

24. Todorović, M. (2009). Credit risk management in the bank, Economic horizons, 11, (2). 81-99

25. Uzuna, V., Shagaidaa, N., Lermanb, Z (2019). Russian agriculture: Growth and institutional challenges, Land Use Policy 83, Elsevier. 475-487

26. Zakić, V. , Kljajić, N. (2016). Analysis of the state of financial literacy of agricultural producers and models of financing agricultural production in the Republic of Serbia, Improvement of financial knowledge and records on agricultural holdings in the Republic of Serbia, Monograph, Institute of Agricultural Economics, Belgrade, 3-22

27. Zelenović, V., Vojinović, Ž., Cvijanović, D. (2018). Serbian agriculture loans with the aim of improving the current situation, Economics of Agriculture, Vol. 65, No. 1, 323-336. doi:10.5937/ekoPolj1801323Z 


\title{
EFEKTI KREDITNOG FINANSIRANJA POLJOPRIVREDE NA DRUŠTVENI PROIZVOD U POLJOPRIVREDI U REPUBLICI SRBIJI
}

\author{
Ranisavljević Duško
}

Sažetak: Bankarski sektor poslednjih godina sve više se okreće ka sektoru poljoprivrede. Primetan je porast ukupnih potraživanja bankarskog sektora od registrovanih poljoprivrednih gazdinstava $u$ periodu 2012-2020. godine, dok je deo društvenog proizvoda koji generiše sektor poljoprivrede takođe zabeležio rast, ali ne u istom procentu kao i bankarski krediti poljoprivredi. Cilj rada je ispitivanje međuzavisnosti porasta ukupnih potraživanja banaka od registrovanih poljoprivrednih proizvođača sa porastom društvenog proizvoda koji generiše sektor poljoprivrede. U radu je korišćena metoda statističke korelacije. Analizira se i uticaj i promene investicionih kredita $u$ poljoprivredi, kredita za obrtna sredstva, ali i kretanje potraživanja banaka po osnovu kamata i naknada od poljoprivrednih proizvođača. Zaključak je da postoji povezanost kredita i društvenog proizvoda sektora poljoprivrede, ali da postoje i drugi faktori koji imaju uticaja. Iako je poslednjih godina bankarski sektor otvoreniji prema sektoru poljoprivrede, iako su krediti jeftiniji, neophodno je stvarati uslove za još veću dostupnost kredita poljoprivrednim proizvođačima, što bi stvorilo pozitivne efekte na poljoprivredu u celini.

Ključne reči: kreditiranje poljoprivrede, investicioni krediti $u$ poljoprivredi, društveni proizvod. 